\title{
Sex-dependent effects of prenatal food and protein restriction on offspring physiology in rats and mice: systematic review and meta-analyses
}

\author{
Julian K. Christians ${ }^{1,2,3,4^{*}}$ (D), Haroop K. Shergill ${ }^{1}$ and Arianne Y. K. Albert ${ }^{4}$
}

\begin{abstract}
Background: Males and females may experience different effects of early-life adversity on life-long health. One hypothesis is that male foetuses invest more in foetal growth and relatively less in placental growth, and that this makes them susceptible to poor nutrition in utero, particularly if nutrition is reduced part-way through gestation.

Objectives: Our objectives were to examine whether (1) food and/ or protein restriction in rats and mice has consistent sex-dependent effects, (2) sex-dependency differs between types of outcomes, and (3) males are more severely affected when restriction starts part-way through gestation.

Data sources: PubMed and Web of Science were searched to identify eligible studies.

Study eligibility criteria: Eligible studies described controlled experiments that restricted protein or food during gestation in rats or mice, examined physiological traits in offspring from manipulated pregnancies, and tested whether effects differed between males and females.

Results: Our search identified 292 articles, of which the full texts of 72 were assessed, and 65 were included for further synthesis. A majority (50) used Wistar or Sprague-Dawley rats and so these were the primary focus. Among studies in which maternal diet was restricted for the duration of gestation, no type of trait was consistently more severely affected in one particular sex, although blood pressure was generally increased in both sexes. Meta-analysis found no difference between sexes in the effect of protein restriction throughout gestation on blood pressure. Among studies restricting food in the latter half of gestation only, there were again few consistent sex-dependent effects, although three studies found blood pressure was increased in males only. Meta-analysis found that food restriction in the second half of gestation increased adult blood pressure in both sexes, with a significantly greater effect in males. Birthweight was consistently reduced in both sexes, a result confirmed by meta-analysis.

(Continued on next page)
\end{abstract}

\footnotetext{
* Correspondence: julian_christians@sfu.ca

${ }^{1}$ Department of Biological Sciences, Simon Fraser University, 8888 University Drive, Burnaby, British Columbia V5A 1S6, Canada

${ }^{2}$ Centre for Cell Biology, Development and Disease, Simon Fraser University, Burnaby, Canada

Full list of author information is available at the end of the article
}

(c) The Author(s). 2021 Open Access This article is licensed under a Creative Commons Attribution 4.0 International License, which permits use, sharing, adaptation, distribution and reproduction in any medium or format, as long as you give appropriate credit to the original author(s) and the source, provide a link to the Creative Commons licence, and indicate if changes were made. The images or other third party material in this article are included in the article's Creative Commons licence, unless indicated otherwise in a credit line to the material. If material is not included in the article's Creative Commons licence and your intended use is not permitted by statutory regulation or exceeds the permitted use, you will need to obtain permission directly from the copyright holder. To view a copy of this licence, visit http://creativecommons.org/licenses/by/4.0/. The Creative Commons Public Domain Dedication waiver (http://creativecommons.org/publicdomain/zero/1.0/) applies to the data made available in this article, unless otherwise stated in a credit line to the data. 
(Continued from previous page)

Conclusions: We found little support for the hypotheses that males are more affected by food and protein restriction, or that effects are particularly severe if nutrition is reduced part-way through gestation. However, less than half of the studies tested for sex by maternal diet interactions to identify sex-dependent effects. As a result, many reported sex-specific effects may be false positives.

Keywords: Developmental origins, Developmental programming, Maternal nutrition, Malnutrition, Prenatal exposure

\section{Background}

Males and females may experience different effects of early-life adversity on long-term health outcomes including cognition and mental health [1-5], as well as metabolic, cardiovascular, and renal disease [6-8]. It has been suggested that male foetuses may be more vulnerable to food shortage [9], and others have since suggested that males may have greater susceptibility to early-life adversity more generally [4]. This difference may be due to a male strategy to prioritize growth, even in the face of adversity, whereas females are more conservative in allocating resources to growth and show more physiological adjustments to challenges $[1,2]$. A potential explanation for this difference in early-life strategies is that there is greater competition for mates among males, making it adaptive to prioritize growth and risk early death, rather than prioritize short-term survival and risk later life reproductive opportunities. Elevated competition among males is one theory to explain sexual size dimorphism in mammals [10, 11], and indeed early postnatal growth has been linked to later life reproductive strategy in male humans [12]. A related hypothesis is that, to maximize foetal growth, males invest less in placental growth, and as a result have to make compensatory investments in the placenta at the expense of the foetus if they encounter poor nutrition later in pregnancy [9].

These hypotheses are particularly relevant to prenatal insults such as malnutrition, but are difficult to test in humans. Many studies rely on associations with birthweight, but this is multifactorial and not determined solely by maternal diet. Studies of famines are informative, and some are able to examine effects of malnutrition at specific time points in gestation [13], but these are confounded by other aspects of maternal stress. Carefully controlled experiments with animal models are therefore needed to understand sex-dependent responses to early-life adversity. Rodents are frequently used as models to investigate the effects of prenatal maternal nutrition on offspring health [14-16] and, given sexual dimorphism and competition among males, rodents would be expected to show similar sex-dependent strategies to humans.

The purpose of this systematic review is to examine the effects of food and protein restriction in rats and mice to test the hypothesis that impaired prenatal nutrition has greater effects on males than on females. We predict that, if male foetuses invest more in foetal growth and relatively less in placental growth [9], and are less responsive to stress signals [1, 2], then food restriction beginning mid-gestation will have particularly deleterious effects on males. Exposure to nutritional restriction throughout pregnancy is expected to constrain the growth of both sexes, whereas if food quantity and/ or quality decreases abruptly part-way through gestation, males will be disproportionately affected if they have prioritized growth and maintained less reserve capacity earlier in pregnancy [9]. We sought to assess whether (1) food and/ or protein restriction in rats and mice has consistent sex-dependent effects, (2) sex-dependency differs between types of outcomes, and (3) males are more severely affected when restriction starts part-way through gestation.

\section{Methods}

We followed the Preferred Reporting Items for Systematic Reviews and Meta-Analyses (PRISMA) guidelines [17]. The review protocol is described below and has not been registered.

\section{Data sources and search}

PubMed and Web of Science were searched using the terms: (prenatal OR maternal) AND (fetal OR fetus) AND (rat OR rodent OR mouse OR mice) AND (sex specific OR sex dependent OR sex difference OR gender difference OR gender specific) AND (restriction OR restricted OR undernutrition OR undernourished OR malnutrition OR "low protein" OR deprivation) on June 4, 2020 .

\section{Eligibility criteria}

The participants, interventions, comparisons, outcomes, and study design (PICOS) criteria were as follows: participants were mice or rats; intervention was macronutrient restriction (protein or food) during gestation (manipulations may have been introduced prior to pregnancy or may have been conducted for only part of pregnancy); comparison was with a control diet provided ad libitum; outcomes were examined in offspring from 
manipulated pregnancies (i.e. effects on subsequent generations were not included); study design was a controlled experiment where offspring sex was taken into account (either by analysing the sexes separately, or by testing for a statistical interaction between treatment and sex). Only studies published in English were included. Reviews were excluded.

\section{Study selection, data items, and summary measures}

Titles and abstracts were screened for relevance. Eligible full texts were assessed to extract the following variables: species and strain, manipulation (protein vs. food restriction), timing and duration of manipulation, severity of the manipulation, sample size per group (i.e. the number of dams manipulated), effects of manipulation on litter size and sex ratio, how offspring sex was taken into account (i.e. analysing the sexes separately or testing for an interaction), and how/whether analyses accounted for multiple offspring per dam. In addition, we recorded offspring traits that were reported to be affected by the manipulation in one or both sexes. Traits were not included where sexes were pooled.

Where other treatments in addition to protein or food restriction were involved, we focused on the effects of protein or food restriction on controls, e.g. if offspring were weaned onto a high-fat diet or control diet, we only included the results from offspring on the control diet. Similarly, where cross-fostering of pups allowed the effects of manipulation during pregnancy to be distinguished from those of manipulation during lactation, we included only the effects of prenatal manipulation.

Because we focused on animal studies, for which protocols are generally not published ahead of time, we could not assess outcome reporting bias. We assumed that animals were assigned to experimental groups at random, and therefore that there was little risk of bias within individual studies. We acknowledge that statistically significant effects were more likely to be reported.

\section{Meta-analyses}

We performed meta-analyses on traits measured in three or more studies with similar protocols where the trait was measured at the same age. Where data were provided in figures, they were extracted using WebPlotDigitizer [18].We used random effects meta-analysis as implemented in the R package 'metafor' [19] to calculate the estimated average standardized mean difference (SMD). SMD were weighted by the inverse variance, which gives greater weight to larger studies. The $\mathrm{I}^{2}$ metric was calculated to assess study heterogeneity. We conducted a moderated meta-analysis to compare the effects in males vs. the effects in females. This involves estimating the treatment effect in males and females separately in each study, and then including sex as a moderator in the meta-regression. We then estimated whether the treatment effect differed by sex. Residual variance was allowed to differ in each sex within each study.

\section{Results}

\section{Study selection}

The PubMed search identified 168 results, while the Web of Science search identified 216 and 292 remained after deduplication (Fig. 1). After screening titles and abstracts for relevance, the full texts of 72 articles were assessed, with a further 7 excluded at this stage ( 2 did not clearly distinguish effects of prenatal maternal diet from other effects; 1 did not define the level of food restriction; 1 only reported effects on a subsequent generation; 1 did not include wild-type control animals; 1 manipulated diet prior to mating but not during gestation; 1 full text from 1994 could not be accessed), and 65 included for further synthesis.

\section{Study characteristics}

All data extracted from the 65 studies are provided in Additional file 1. Of these studies, 29 used Wistar rats (23 performed protein restriction [20-42] and 6 performed food restriction [43-48]), 21 used SpragueDawley rats (7 protein restriction [49-55] and 14 food restriction [56-69]), 3 used other strains of rats (2 protein restriction with Wistar-Kyoto [70, 71] and 1 food restriction with Long Evans [72]) and 12 used various strains of mice (7 protein restriction [73-79] and 5 food restriction [80-84]). We therefore focused primarily on studies of Wistar and Sprague-Dawley rats.

\section{Sex-dependent effects of food or protein restriction in rats}

We categorized offspring traits (Table 1) to facilitate comparisons of different types of outcomes. To address the question of whether food and/ or protein restriction has consistent sex-dependent effects, we then summarized the types of traits that were affected to a greater extent in males, those affected to a greater extent in females, and those affected in both sexes.

We first focused on studies in which maternal diet was restricted for the duration of gestation in Wistar or Sprague-Dawley rats (Table 2). To reduce heterogeneity in experimental design, this summary excluded 4 studies of Wistar rats [23, 25, 36, 37] and 1 of Sprague-Dawley rats [50] that also manipulated diet throughout lactation (without cross-fostering to distinguish effects of gestation and lactation), and 1 study of Sprague-Dawley rats that began restriction 3 weeks before breeding [49]. Although excluded from Table 2, the results of these studies are summarized in Additional file 1. 


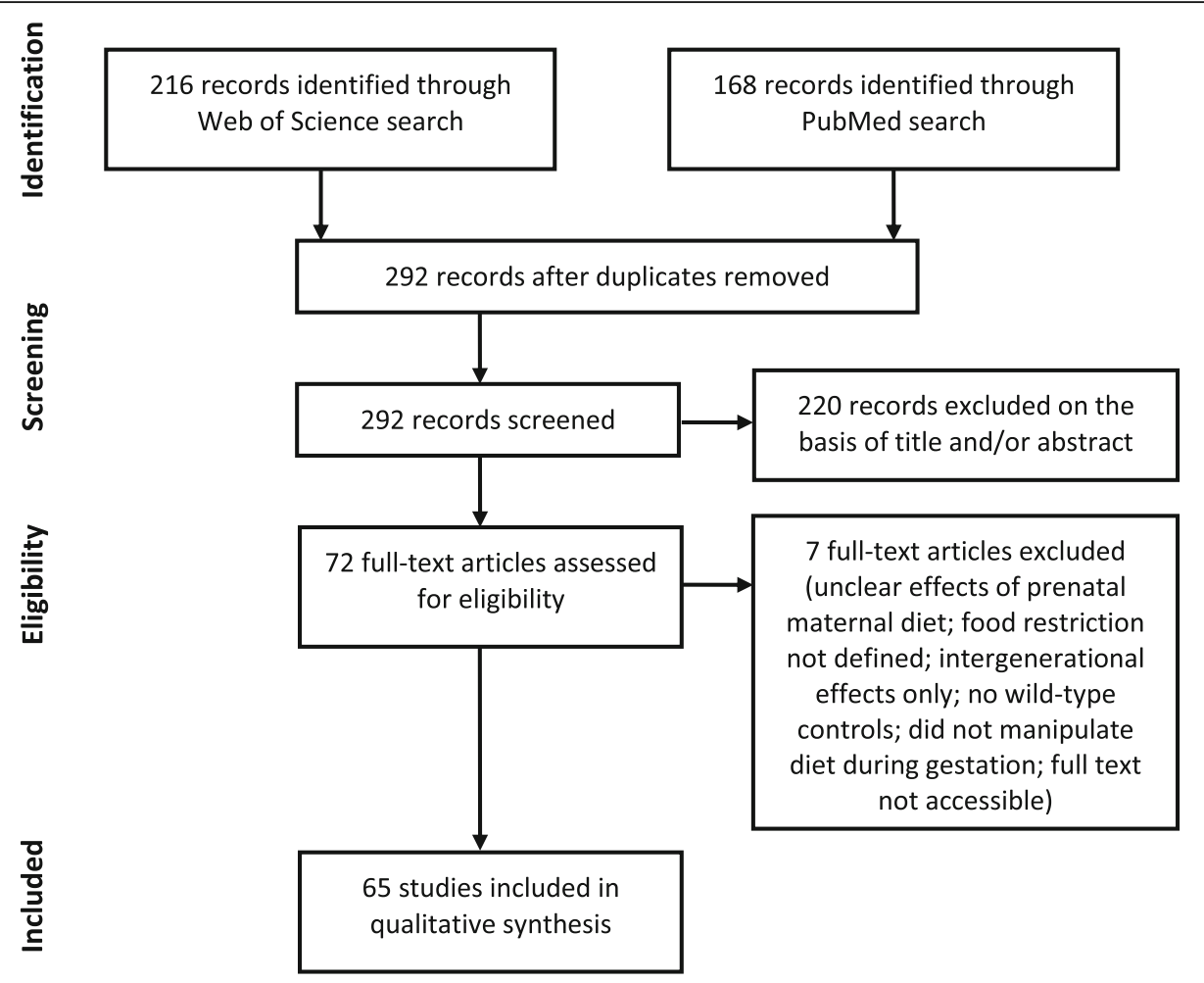

Fig. 1 PRISMA flow diagram showing selection process (figure template from [17])

Table 1 Categories used to group traits

\begin{tabular}{|c|c|}
\hline Category $^{a}$ & Examples of traits \\
\hline Adrenal & gene expression (mRNA or protein); organ weight \\
\hline Behavioural & stereotypic responses; food intake; food preference \\
\hline Blood lipids & cholesterol, LDL, NEFA, triglycerides \\
\hline Bone & bone mineral content, bone mineral density \\
\hline Brain & gene expression (mRNA or protein) \\
\hline Cardiovascular & $\begin{array}{l}\text { blood pressure; measures of vascular or ventricular function; } \\
\text { heart rate; gene expression (mRNA or protein) in heart or } \\
\text { vasculature; organ weight }\end{array}$ \\
\hline Fat & body fat percentage, fat pad weight \\
\hline Hepatic & $\begin{array}{l}\text { hepatic gene expression, enzyme activity, glycogen, blood } \\
\text { proteins produced by liver; organ weight }\end{array}$ \\
\hline Lung & $\begin{array}{l}\text { alveolar number, gene expression (mRNA or protein); triolein } \\
\text { uptake; organ weight }\end{array}$ \\
\hline Muscular & fibre density, diameter \\
\hline Oxidative status & $\begin{array}{l}\text { plasma carbonyl, glutathione, thiols and melatonin, } \\
\text { superoxide anion scavenging activity, oxidative status } \\
\text { score based on plasma biomarkers }\end{array}$ \\
\hline Pancreatic & $\begin{array}{l}\text { beta-cell mass; islet size; gene expression (mRNA or protein); } \\
\text { organ weight }\end{array}$ \\
\hline Placental & gene expression (mRNA or protein), SOD activity \\
\hline Renal & $\begin{array}{l}\text { gene expression (mRNA or protein); urine production; ion } \\
\text { excretion; glomerular number; glomerular filtration rate; organ } \\
\text { weight }\end{array}$ \\
\hline Spleen & organ weight \\
\hline
\end{tabular}

${ }^{\mathrm{a} B o d y}$ weight, blood hormones, and blood glucose were not categorized 
Table 2 Traits affected by food restriction (FR) or protein restriction (PR) throughout gestation in rats

\begin{tabular}{|c|c|c|c|c|c|c|}
\hline Study & $N^{\mathrm{a}}$ & Manipulation & $\begin{array}{l}\text { Traits affected } \\
\text { in males }\end{array}$ & $\begin{array}{l}\text { Traits affected } \\
\text { in females }\end{array}$ & $\begin{array}{l}\text { Traits affected } \\
\text { in both sexes }\end{array}$ & $\begin{array}{l}\text { Analysed sexes } \\
\text { separately or } \\
\text { tested interaction }\end{array}$ \\
\hline \multicolumn{7}{|l|}{ Wistar rats } \\
\hline Howie 2012 [43] & 6 & FR $(50 \%)$ & $\begin{array}{l}\text { Insulin:leptin ratio; } \\
\text { blood lipids; hepatic; } \\
\text { spleen }\end{array}$ & Hepatic & $\begin{array}{l}\text { Birthweight; body weight; } \\
\text { fat; bone; leptin; blood lipids }\end{array}$ & Sexes separately \\
\hline Ozaki 2001 [44] & $\begin{array}{l}10- \\
11\end{array}$ & FR (70\%) & Cardiovascular & Cardiovascular & Cardiovascular & Sexes separately \\
\hline Peiris 2010 [45] & $?$ & FR (30\%) & Insulin & Fat & Body weight & Interaction \\
\hline $\begin{array}{l}\text { Sánchez-Garrido } \\
2013 \text { [46] }\end{array}$ & $?$ & FR (70\%) & Body weight; insulin ${ }^{d}$ & $\begin{array}{l}\text { Body weight; } \\
\text { insulin }\end{array}$ & Birthweight; FSH & Sexes separately \\
\hline Alwasel 2009 [20] & $?$ & $\begin{array}{l}\text { PR } \\
(9 \% \text { vs } 18 \%)\end{array}$ & None & None & Cardiovascular; renal & Interaction \\
\hline Bellinger $2006^{\mathrm{b}}$ [22] & $8-11$ & $\begin{array}{l}\text { PR } \\
\text { (9\% vs } 18 \%)\end{array}$ & Body weight; fat & Fat; behavioural & None & Interaction \\
\hline Cooke 2014` [24] & 6 & $\begin{array}{l}\text { PR } \\
\text { ( } 8 \% \text { vs 20\%) }\end{array}$ & Renal & Renal & Foetal weight; renal & Sexes separately \\
\hline Elmes 2007 [26] & 8 & $\begin{array}{l}\text { PR } \\
(9 \% \text { vs } 18 \%)\end{array}$ & Cardiovascular & None & Cardiovascular & Interaction \\
\hline Elmes 2009 [27] & 6 & $\begin{array}{l}\text { PR } \\
(9 \% \text { vs } 18 \%)\end{array}$ & Cardiovascular ${ }^{\mathrm{e}}$ & Cardiovascular & Cardiovascular & Interaction \\
\hline Kwong $2006^{\mathrm{b}}$ [28] & $\begin{array}{l}11- \\
13\end{array}$ & $\begin{array}{l}\text { PR } \\
(9 \% \text { vs } 18 \%)\end{array}$ & None & None & None & Not clear \\
\hline Kwong $2007^{\mathrm{b}}[29]$ & $\begin{array}{l}11- \\
13\end{array}$ & $\begin{array}{l}\text { PR } \\
(9 \% \text { vs } 18 \%)\end{array}$ & Hepatic & None & None & Sexes separately \\
\hline $\begin{array}{l}\text { Langley-Evans } 1997 \\
\text { [30] }\end{array}$ & 3 & $\begin{array}{l}\text { PR } \\
\text { (9\% vs 18\%) }\end{array}$ & Lung; renal; brain & None & Body weight; cardiovascular & Sexes separately \\
\hline $\begin{array}{l}\text { Langley-Evans } 2005 \\
\text { [31] }\end{array}$ & 7 & $\begin{array}{l}\text { PR } \\
\text { (9\% vs } 18 \%)\end{array}$ & Hepatic & None & None & Interaction \\
\hline $\begin{array}{l}\text { Langley-Evans } 2006 \\
\text { [32] }\end{array}$ & $5-8$ & $\begin{array}{l}\text { PR } \\
\text { (9\% vs } 18 \%)\end{array}$ & None & $\begin{array}{l}\text { Placental weight; } \\
\text { hepatic }\end{array}$ & Placental weight & Interaction \\
\hline Mallinson $2007^{\mathrm{b}}[33]$ & $\begin{array}{l}11- \\
13\end{array}$ & $\begin{array}{l}\text { PR } \\
(9 \% \text { vs } 18 \%)\end{array}$ & Muscular & None & None & Interaction \\
\hline McMullen 2005 [34] & 6 & $\begin{array}{l}\text { PR } \\
\text { (9\% vs } 18 \%)\end{array}$ & None & Cardiovascular; renal & Cardiovascular & Interaction \\
\hline McMullen 2005 [35] & $\begin{array}{l}10- \\
11\end{array}$ & $\begin{array}{l}\text { PR } \\
\text { ( } 9 \% \text { vs } 18 \%)\end{array}$ & None & Renal & Renal & Interaction \\
\hline Theys 2009 [38] & 7 & $\begin{array}{l}\text { PR } \\
(8 \% \text { vs } 20 \%)\end{array}$ & Blood lipids; pancreatic & Pancreatic; hepatic & Birthweight; pancreatic & Interaction \\
\hline Torrens 2009 [39] & $6-7$ & $\begin{array}{l}\text { PR } \\
\text { (9\% vs } 18 \%)\end{array}$ & $\begin{array}{l}\text { Cardiovascular; blood } \\
\text { inflammatory markers }\end{array}$ & None & Cardiovascular & Sexes separately \\
\hline Vega 2016 [40] & 6 & $\begin{array}{l}\text { PR } \\
\text { (10\% vs 20\%) }\end{array}$ & $\begin{array}{l}\text { Placental; foetal hepatic } \\
\text { blood lipids; hepatic }\end{array}$ & $\begin{array}{l}\text { Placental; foetal } \\
\text { hepatice; fat; hepatic }\end{array}$ & $\begin{array}{l}\text { Foetal weight; foetal:placental } \\
\text { ratio; placental; foetal hepatic; } \\
\text { hepatic; leptin; corticosterone; } \\
\text { insulin }\end{array}$ & Sexes separately \\
\hline Ye 2018 [41] & $7-10$ & $\begin{array}{l}\text { PR } \\
\text { (10\% vs } 20 \%)\end{array}$ & None & Brain; behavioural & None & Interaction \\
\hline Zambrano 2006 [42] & $4-6$ & $\begin{array}{l}\text { PR } \\
\text { (10\% vs } 20 \%)\end{array}$ & $\begin{array}{l}\text { Leptin; glucose; blood } \\
\text { lipids }\end{array}$ & Birthweight; fat & Insulin & Sexes separately \\
\hline \multicolumn{7}{|l|}{ Sprague-Dawley rats } \\
\hline Gao $2012^{d}[51]$ & 10 & $\begin{array}{l}\text { PR } \\
(6 \% \text { vs } 20 \%)\end{array}$ & Placental & Placental & $\begin{array}{l}\text { Foetal weight; placental } \\
\text { weight; placental }\end{array}$ & Interaction \\
\hline Gao $2012^{d}[52]$ & 10 & $\begin{array}{l}\text { PR } \\
\text { (6\% vs } 20 \%)\end{array}$ & Placental & Placental & Foetal weight; placental & Interaction \\
\hline
\end{tabular}


Table 2 Traits affected by food restriction (FR) or protein restriction (PR) throughout gestation in rats (Continued)

\begin{tabular}{|c|c|c|c|c|c|c|}
\hline Study & $N^{\mathrm{a}}$ & Manipulation & $\begin{array}{l}\text { Traits affected } \\
\text { in males }\end{array}$ & $\begin{array}{l}\text { Traits affected } \\
\text { in females }\end{array}$ & $\begin{array}{l}\text { Traits affected } \\
\text { in both sexes }\end{array}$ & $\begin{array}{l}\text { Analysed sexes } \\
\text { separately or } \\
\text { tested interaction }\end{array}$ \\
\hline $\begin{array}{l}\text { Sathishkumar } \\
2012 \text { [53] }\end{array}$ & $8-9$ & $\begin{array}{l}\text { PR } \\
\text { (6\% vs 20\%) }\end{array}$ & Cardiovascular & Cardiovascular & Cardiovascular & Sexes separately \\
\hline Woods 2004 $[54]$ & $6-9$ & $\begin{array}{l}\text { PR } \\
\text { (5\% vs 19\%) }\end{array}$ & Body weight; renal & None & $\begin{array}{l}\text { Body weight; } \\
\text { cardiovascular; } \\
\text { renal }\end{array}$ & $\begin{array}{l}\text { Sexes separately } \\
\text { and interaction }\end{array}$ \\
\hline Woods 2005 [55] & $\begin{array}{l}13- \\
16\end{array}$ & $\begin{array}{l}\text { PR } \\
\text { (9\% vs 19\%) }\end{array}$ & Renal & None & Birthweight & Sexes separately \\
\hline
\end{tabular}

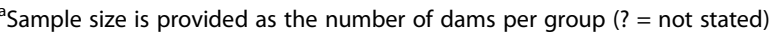

${ }^{b}$ Study also manipulated diet during various periods of gestation. This table includes only results of manipulation throughout gestation

'Study also includes a group where manipulation continued through lactation. This table includes only results from dams collected during gestation

${ }^{\mathrm{d}}$ Study collected at day 14 and 18 of gestation

'Manipulation had opposite effect in males and females for some traits

In both Wistar and Sprague-Dawley rats (Table 2), no type of trait was consistently more severely affected in one particular sex. For example, cardiovascular traits were studied most frequently, and some studies found such traits to be more affected in males, while others found females to be more affected, and other studies found some traits to be more affected in males and some to be more affected in females. Considering all types of traits, more studies (8 out of 27) found some traits to be more affected in males and no traits to be more affected in females, compared with the reverse scenario (4 out of 27). However, of the 12 studies that found sexdependent effects in one sex but not the other, the proportion with male-specific effects was not significantly greater than half ( $p=0.39$, two-tailed binomial test).

Some traits were examined in more than one study, allowing more detailed assessment of the consistency of sex-dependent effects. Considering offspring of Wistar and Sprague-Dawley dams protein-restricted for the duration of gestation (studies listed in Table 2; complete data provided in Additional file 1), birthweight was reduced in both sexes in one study [38], but in another was reduced in females but not males [42]. Conversely, weight at 3 weeks [54] and 7 weeks of age [30] was reduced in both sexes, whereas weight at 4 [22], 22, and 35 weeks [54] was reduced only in males. Blood pressure was generally increased in both sexes [20, 26, 30, 34, 54], although in one study, this was true at 6 months of age, but at 3 months, only males were affected [53]. Heart rate was sometimes increased in both sexes [26], sometimes in females only [34]. Blood triglycerides were increased in males in two studies $[38,42]$. Serum insulin was increased in both sexes [40,42], as was serum leptin in one study [40], although leptin was increased only in males in another [42].

Because blood pressure and birthweight (including weight at foetal day 20 or 21 or postnatal day 1) were measured in three or more studies, we performed meta-analyses for these traits. Protein restriction for the duration of gestation reduced birthweight in females $(p=0.01)$, and tended to reduce birthweight in males, although the latter difference was marginally non-significant ( $p=0.06$; Fig. 2$)$. There was no difference in the effect of protein restriction between males and females $(p=0.86)$. Protein restriction for the duration of gestation increased blood pressure in juvenile (4-5 weeks old; Fig. 3) and adolescent (7-13 weeks old; Fig. 4) males (juveniles: $p=0.04$; adolescents: $p<0.0001$ ) and females (juveniles: $p=0.02$; adolescents: $p=0.006$ ), but there was no difference in effect between males and females (juveniles: $p=$ 0.78 ; adolescents: $p=0.47$ ). The data extracted from individual studies for the meta-analyses are provided in Additional file 1.

\section{Effects of food or protein restriction occurring in the latter half of gestation}

To assess our prediction that males would be more severely affected when restriction starts part-way through gestation, we examined studies manipulating maternal diet for part of gestation. Fourteen studies applied food restriction in the latter half of gestation (generally beginning at gestational day (GD) 10 or 11) in SpragueDawley rats (Table 3). Of these 14 studies, 4 found some traits to be more affected in males and no traits to be more affected in females, whereas no study found the reverse (Table 3; complete data provided in Additional file 1). However, 4 out of 4 studies finding sex-dependent effects in males but not females is not significantly greater than half, i.e. if studies finding female-specific effects but no male-specific effects were equally likely $(p=0.13$, two-tailed binomial test).

Birthweight (including weight 1 day after birth) was consistently reduced in both sexes [56, 59, 60, 63, 65-68]. Similarly, body weight was reduced in both sexes at 7 days [65] and at 21 days [66], but was 


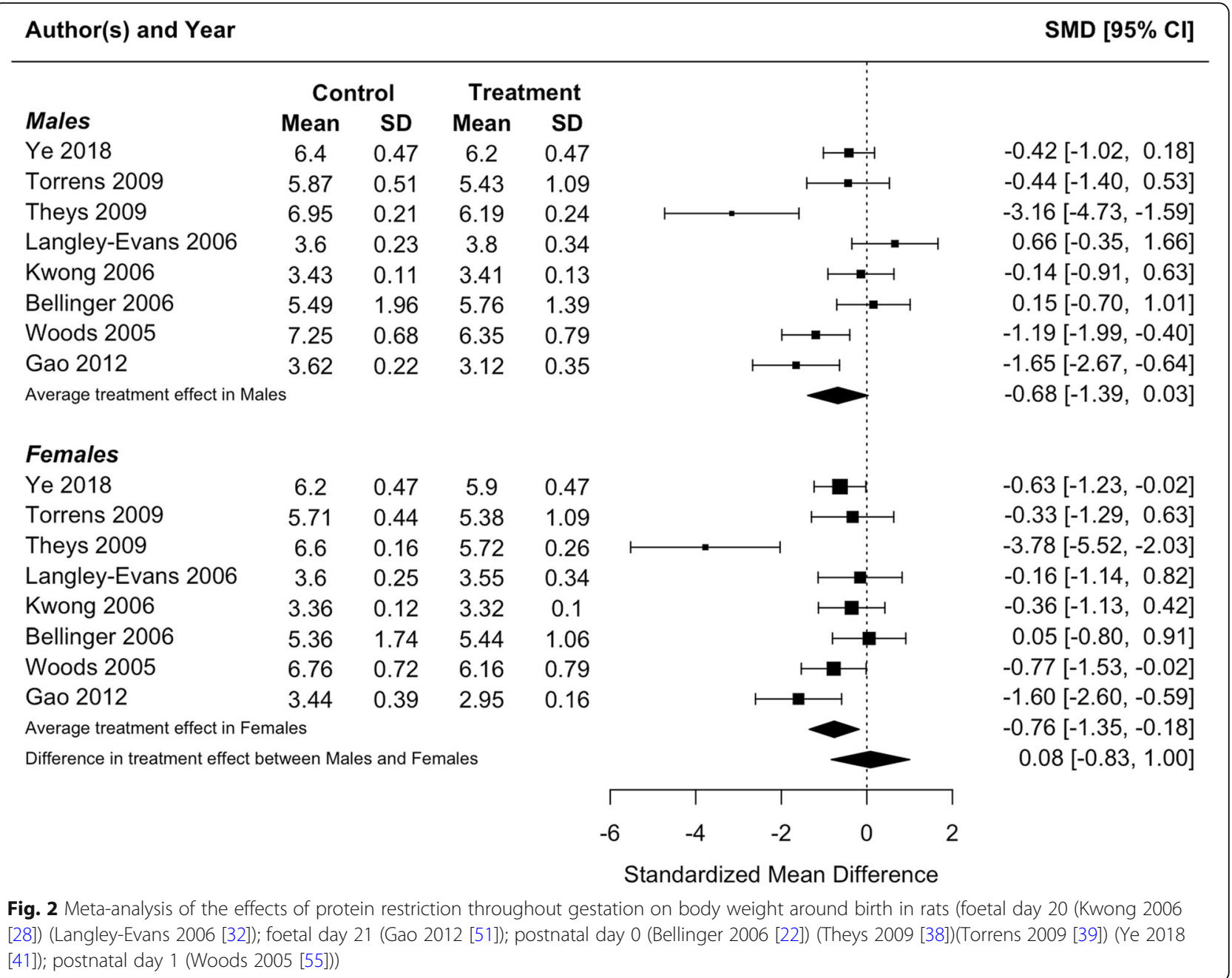

increased in both sexes at 6 months and 9 months of age $[58,61,62]$, although some studies found it to be reduced in males only at 3 days [62] and 21 days [63]. Blood pressure was increased in males only [59, 67, 68].

Consistent with the results of individual studies, a meta-analysis found that food restriction in the second half of gestation reduced birthweight in females $(p=0.002)$ and males $(p<0.0001)$, but that there was no difference in the effect of protein restriction between males and females (Fig. 5; $p=0.63$ ). Metaanalysis of food restriction in the second half of gestation found no effect on blood pressure in juveniles (4-5 weeks old; Fig. 6), and no difference in effect between males and females $(p=0.13)$. However, in adults (6 months old), a meta-analysis found that blood pressure was increased in both males $(p<$ $0.0001)$ and females $(p=0.02)$, with a significantly greater effect in males ( $p=0.04$; Fig. 7$)$, in contrast to results from individual studies, where effects were significant in males only $[59,67,68]$. The data extracted from individual studies for the metaanalyses are provided in Additional file 1.

Five studies used multiple groups to manipulate protein levels throughout different periods of gestation (4 in Wistar rats and 1 in Sprague-Dawley rats), allowing effects of restriction late in gestation to be compared with restriction beginning earlier (Table 4). Maternal protein restriction from GD $0-7$ or from GD 15-22 but not from GD 8-14 increased hepatic glycogen concentration in male offspring only [21]. Male-specific effects on 4week weight and 9-month gonadal fat were similar whether protein restriction occurred from GD 15-22 or throughout gestation, although restriction in the last week of gestation also decreased 2-month weight in males only [22]. While some measures of pancreatic islets at day 1 and pancreatic expression of some genes at day 21 were affected in males only by restriction in the last week of pregnancy, no such male-specific effects were observed in offspring of dams restricted throughout gestation and lactation [23]. In contrast, 4-week density of slow fibres in the gastrocnemius muscle was increased 


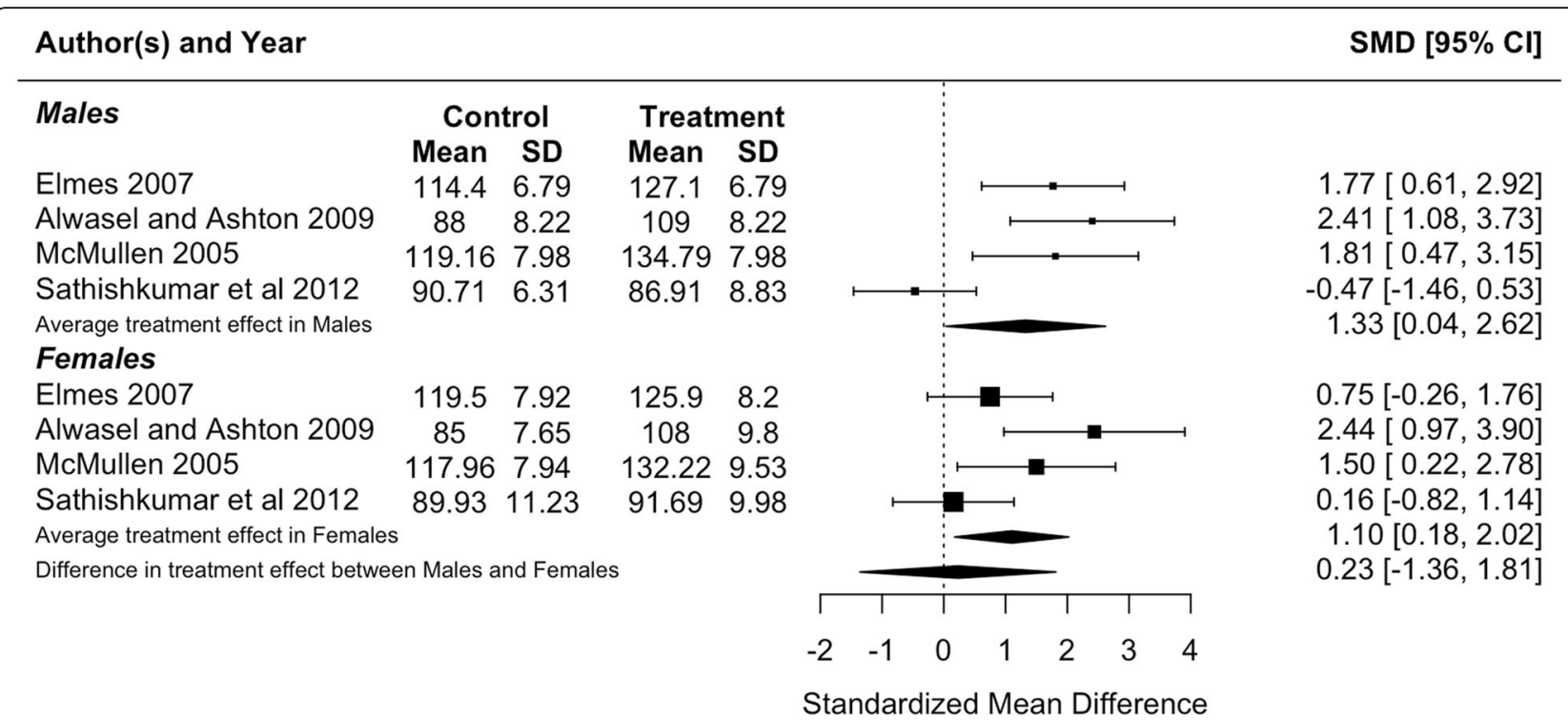

Fig. 3 Meta-analysis of the effects of protein restriction throughout gestation on blood pressure in juvenile rats (mean blood pressure at 4 weeks (Alwasel and Ashton 2009 [20]); systolic blood pressure at 4 weeks (McMullen 2005 [34]) (Elmes 2007 [26]); mean blood pressure at 1 month (Sathishkumar et al 2012 [53]))

in males only by restriction throughout gestation, whereas there were no male-specific effects when restriction occurred in the last week of gestation [33]. Protein restriction, whether from GD 11 to birth or from the beginning of gestation to birth, reduced body weight and glomerular volume at 22 weeks in males but not females, although the reduction in glomerular volume was significantly greater in offspring who experienced protein restriction throughout gestation [54].

\section{Sex-dependent effects of food or protein restriction in} mice

Only 12 studies of mice met our inclusion criteria, and of these, experimental protocols were more variable than those of the rat studies, with a greater proportion beginning maternal nutrient restriction before mating, or continuing restriction through at least part of lactation. Overall, there was no clear pattern of males being more affected than females (Additional file 1). Two studies of

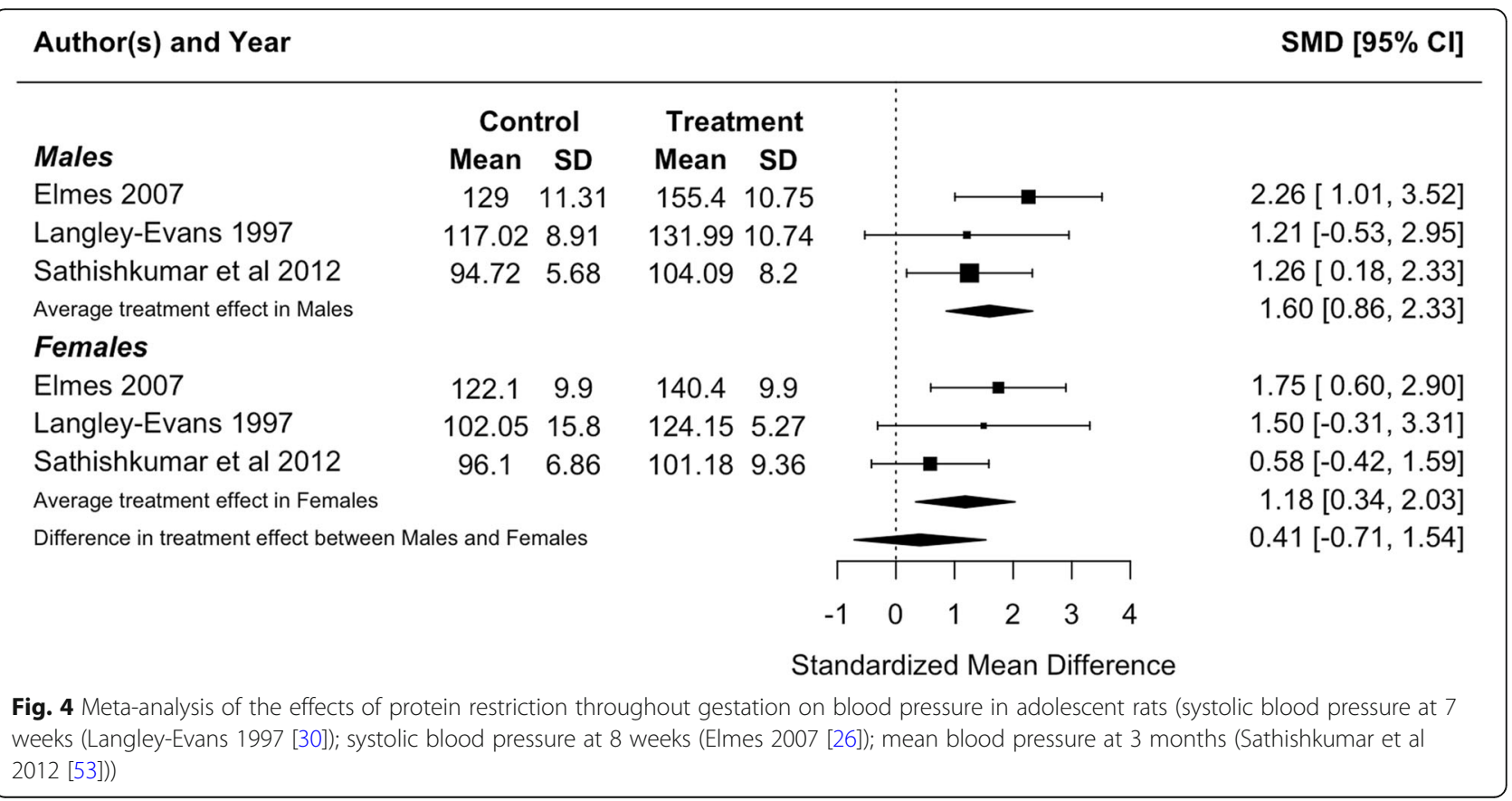


Table 3 Traits affected by food restriction (FR) in the latter half of gestation in Sprague-Dawley rats

\begin{tabular}{|c|c|c|c|c|c|c|c|}
\hline Study & $N^{\mathrm{a}}$ & Manipulation & Duration & $\begin{array}{l}\text { Traits affected } \\
\text { in males }\end{array}$ & $\begin{array}{l}\text { Traits affected } \\
\text { in females }\end{array}$ & $\begin{array}{l}\text { Traits affected in both } \\
\text { sexes }\end{array}$ & $\begin{array}{l}\text { Analysed sexes } \\
\text { separately or } \\
\text { tested interaction }\end{array}$ \\
\hline Choi 2007 [56] & 6 & FR (75\%) & GD 10-birth & Hepatic & Hepatic & Birthweight; hepatic & Sexes separately \\
\hline Desai 2005 [57] & 12 & FR (50\%) & GD 10-birth & None & None & Body weight & Not clear \\
\hline Desai 2007 [58] & 6 & FR (50\%) & GD 10-birth & None & None & $\begin{array}{l}\text { Body weight; fat; leptin; } \\
\text { blood lipids; glucose; } \\
\text { insulin; glucose tolerance } \\
\text { test; behavioural }\end{array}$ & Not clear \\
\hline $\begin{array}{l}\text { Gutierrez-Arzapalo } \\
2018 \text { [59] }\end{array}$ & $3-5$ & FR (50\%) & GD 11-birth & Cardiovascular ${ }^{\mathrm{b}}$ & Cardiovascular ${ }^{\mathrm{b}}$ & Birthweight; cardiovascular & Interaction \\
\hline $\begin{array}{l}\text { Hemmings } 2005 \\
\text { [60] }\end{array}$ & $8-11$ & FR (40\%) & GD 15-birth & Cardiovascular & Cardiovascular & Birthweight & Sexes separately \\
\hline Khorram 2011 [61] & $4-6$ & FR (50\%) & GD 10-birth & $\begin{array}{l}\text { Corticosterone; } \\
\text { adrenal| }^{\mathrm{a}}\end{array}$ & Adrenal $^{\mathrm{a}}$ & Body weight; adrenal & Sexes separately \\
\hline Lee 2013 [62] & 4 & FR (50\%) & GD 10-birth & Body weight & None & $\begin{array}{l}\text { Body weight; fat; blood } \\
\text { lipids; leptin }\end{array}$ & Sexes separately \\
\hline $\begin{array}{l}\text { Matveyenko } \\
2010 \text { [63] }\end{array}$ & 6 & FR (50\%) & GD 11-21 & $\begin{array}{l}\text { Body weight; } \\
\text { pancreatic }\end{array}$ & None & Birthweight; pancreatic & Sexes separately \\
\hline Molle 2015 [64] & 6 & FR (50\%) & GD 10-birth & Behavioural $^{\text {b; }}$ brain & Behavioural $^{b}$ & Behavioural; brain & Interaction \\
\hline $\begin{array}{l}\text { Munoz-Valverde } \\
2015 \text { [65] }\end{array}$ & 12 & FR (50\%) & GD 11-birth & None & None & $\begin{array}{l}\text { Birthweight; cardiovascular; } \\
\text { hepatic; fat; glucose }\end{array}$ & Sexes separately \\
\hline Paek 2015 [66] & 4 & FR (50\%) & GD 10-birth & None & None & $\begin{array}{l}\text { Birthweight; body weight; } \\
\text { lung }\end{array}$ & Not clear \\
\hline $\begin{array}{l}\text { Rodríguez-Rodríguez } \\
2015 \text { [67] }\end{array}$ & 6 & FR (50\%) & GD 11-birth & $\begin{array}{l}\text { Cardiovascular; } \\
\text { oxidative status }\end{array}$ & None & $\begin{array}{l}\text { Birthweight; oxidative } \\
\text { status }\end{array}$ & Sexes separately \\
\hline $\begin{array}{l}\text { Rodríguez-Rodríguez } \\
2017 \text { [68] }\end{array}$ & 5 & FR (50\%) & GD 11-birth & Cardiovascular $^{\mathrm{b}}$ & Cardiovascular ${ }^{\mathrm{b}}$ & Birthweight; cardiovascular & Interaction \\
\hline You 2015 [69] & 5 & FR (50\%) & GD 10-birth & Hepatic; homocysteine & None & None & Sexes separately \\
\hline
\end{tabular}

${ }^{a}$ Sample size is provided as the number of dams per group (? = not stated)

${ }^{\mathrm{b}}$ Manipulation had opposite effect in males and females for some traits

C57BL/6J mice had protocols most comparable with those of the rat studies described above (protein restriction throughout gestation only). In one case, blood pressure at 6 months was increased in male offspring of dams subjected to nutrient restriction, but was decreased in female offspring [73], whereas blood pressure at 20 weeks was increased in both sexes in another study [74].

\section{Analytical approaches}

The number of dams per treatment ranged from 3 to 18 , with a median of 7; a few studies did not report sample sizes in terms of the number of dams (Additional file 1). While most studies found some sex-specific effects, those that did not include studies with both small (3) and moderate $(\sim 12)$ sample sizes (Additional file 1$)$, suggesting that the detection of sex-specific effects was not entirely a function of statistical power. In studies where the prenatal environment is manipulated, it is the dam, not the individual offspring, that is the unit of replication. Therefore, it is necessary to account for the use of multiple pups per litter to avoid pseudoreplication. In most studies, this was achieved by using only one or two animals of each sex from each litter for a given measurement. Less than half of the studies $(28 / 65)$ reported testing for the sex by maternal diet interaction to identify sex-dependent effects. Even in studies that stated that interactions were used, the p-values for the interaction for specific tests were often not reported.

\section{Discussion}

A number of authors have suggested that human males may have greater susceptibility to early-life effects because of a strategy to prioritize growth [1, 2, 4, 9]. The purpose of the present study was to test whether male rats and mice are more susceptible to the effects of food and protein restriction during gestation, experimental approaches that are frequently used to model the development of health and disease in humans. We first sought to assess whether food and/ or protein restriction in rodents has consistent sex-dependent effects, and whether sex-dependency differs between types of outcomes, and found few consistent patterns. Where the same trait was studied in more than one study in offspring of rat dams protein-restricted for the duration of 


\section{Author(s) and Year}

SMD $[95 \% \mathrm{CI}]$

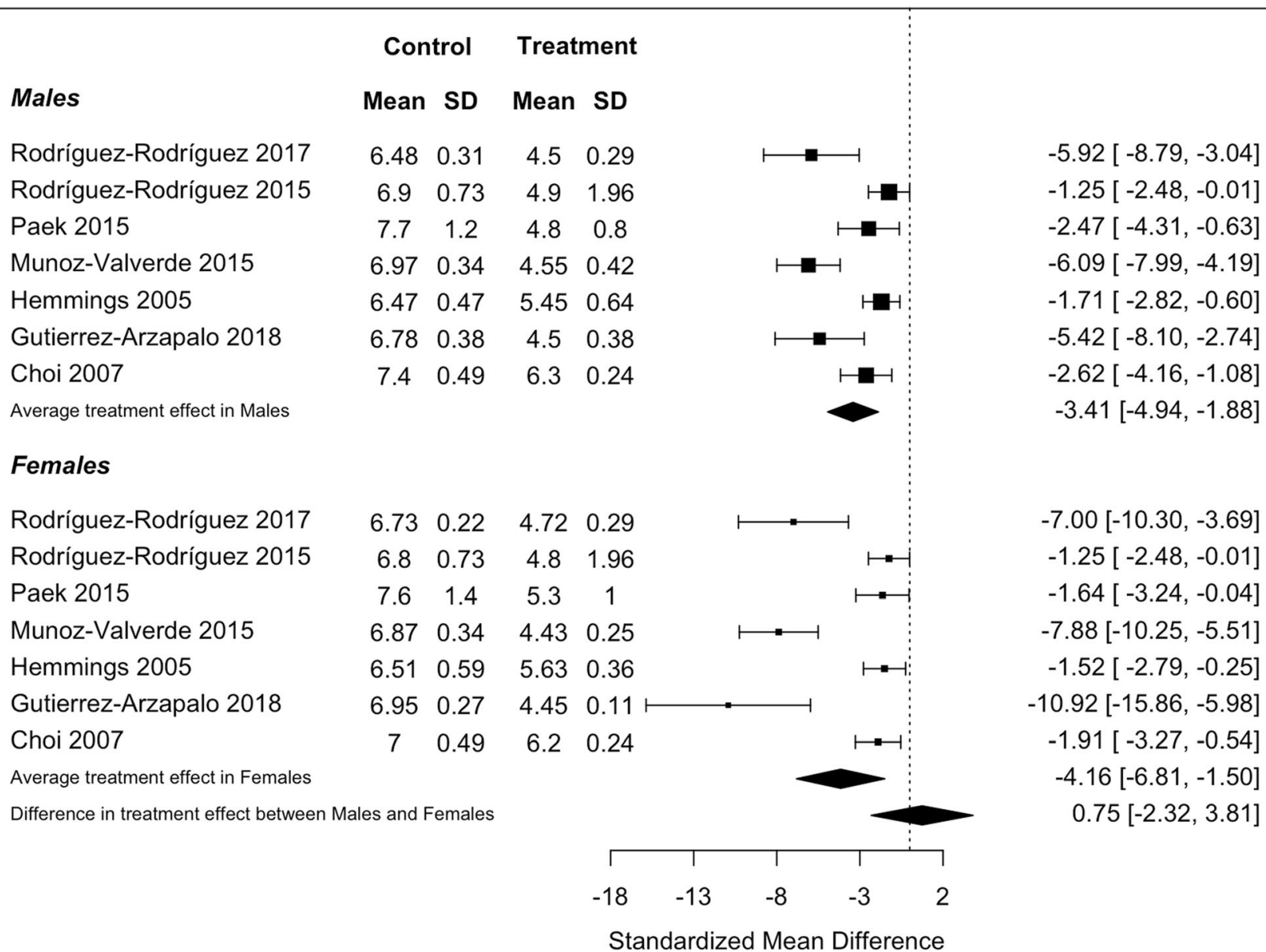

Fig. 5 Meta-analysis of the effects of food restriction in the second half of gestation on body weight around birth in rats (postnatal day 0 (Hemmings 2005 [60]); postnatal day 1 (Choi 2007 [56]) (Gutierrez-Arzapalo 2018 [59]) (Munoz-Valverde 2015 [65]) (Paek 2015 [66]) (RodriguezRodriguez 2015 [67]) (Rodriguez-Rodriguez 2017 [68]))

gestation, sex-specific effects were generally not consistent, although blood pressure was generally increased in both sexes. Whether diet was manipulated throughout gestation or in the latter half of pregnancy, a greater number of studies found some traits affected in males and no traits affected in females rather than the reverse pattern. However, the proportion of studies finding effects in males but not females was not significantly greater than half, and a large majority of studies found at least some traits more severely affected in females.

Given the hypothesis that male foetuses invest more in foetal growth and relatively less in placental growth [9], we predicted that nutritional restriction beginning midgestation will have particularly deleterious effects on males. There was some support for this prediction: When food or protein was restricted throughout gestation, blood pressure was generally affected in both sexes, whereas in three studies where food was restricted in the latter half of pregnancy, blood pressure was affected in males only. However, in a single study that used separate experimental groups to examine protein restriction throughout gestation and in the latter half of gestation only, blood pressure was increased in both sexes with both windows of exposure [54]. More generally, where studies used multiple groups to manipulate protein levels throughout different periods of gestation, there were not consistently more effects when restriction occurred in the latter half of gestation.

The literature we reviewed focused on effects in surviving offspring, but if males are more susceptible to nutritional restriction during gestation, we predict that males would be more likely to die before birth. However, of the 65 studies we examined, 23 found no effect on litter size and only 2 reported a reduction in litter size in nutrient restricted dams; the remainder of the studies did not report effects on litter size (Additional file 1). Although these results suggest that maternal nutrient restriction did not increase male mortality, only 5 studies 


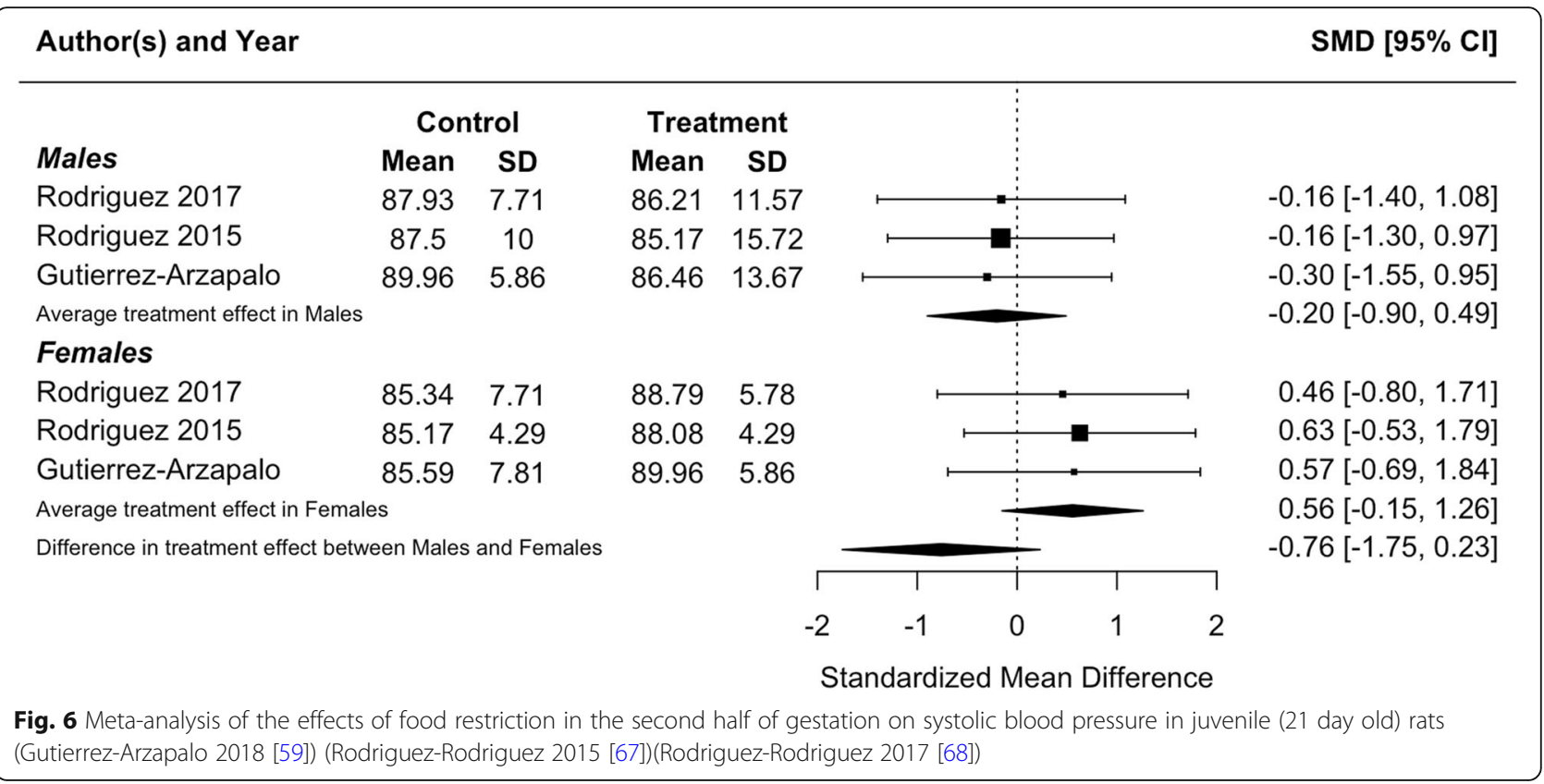

investigated sex ratio at birth, with none reporting an effect of maternal diet. Nevertheless, in future studies, it would be useful to report sex ratio in case the sexes differ in their susceptibility to the manipulation.

A potential contributor to the lack of clear patterns is that this area of research often suffers from a lack of robust statistical testing, whereby authors investigate sexdependence by testing the sexes separately, rather than explicitly testing the statistical interaction between sex and early-life environment. In this review, less than half of the studies described testing interactions, which has been reported previously for studies of humans [1, 4] and of other animal models [85]. The problem with testing the sexes separately can be understood by considering a scenario where an early-life insult has similar effects in males and females. If a study has statistical power of 0.8 to detect such an effect (which is generally considered adequate power, and higher than in many studies [86]), but analyses the sexes separately, then the probability of the effect being significant in both sexes is

\section{Author(s) and Year}

SMD $[95 \% \mathrm{Cl}]$

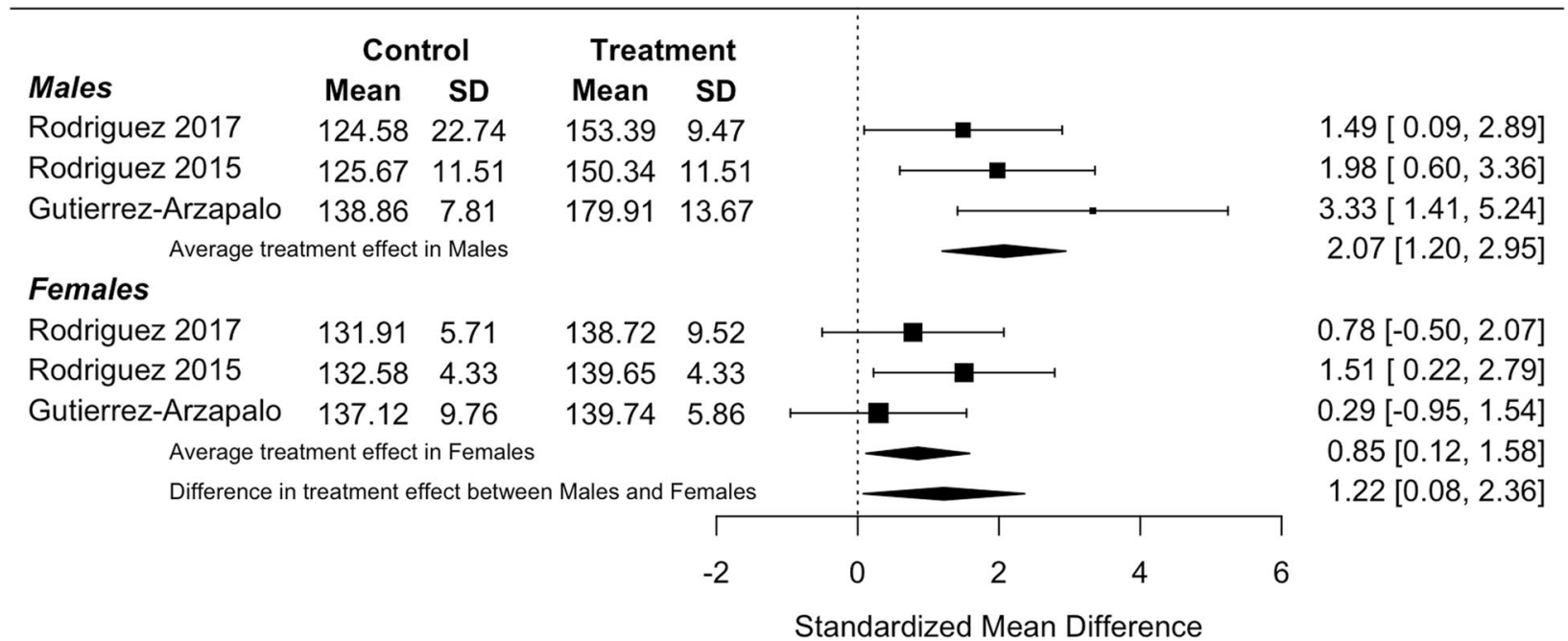

Fig. 7 Meta-analysis of the effects of food restriction in the second half of gestation on systolic blood pressure in adult (6 month old) rats (Gutierrez-Arzapalo 2018 [59]) (Rodriguez-Rodriguez 2015 [67]) (Rodriguez-Rodriguez 2017 [68]) 
Table 4 Traits affected by protein restriction (PR) among studies that manipulated diet in multiple periods of gestation

\begin{tabular}{|c|c|c|c|c|c|c|c|}
\hline Study & $N^{\mathrm{a}}$ & Manipulation & Duration & $\begin{array}{l}\text { Traits affected } \\
\text { in males }\end{array}$ & $\begin{array}{l}\text { Traits affected } \\
\text { in females }\end{array}$ & $\begin{array}{l}\text { Traits affected } \\
\text { in both sexes }\end{array}$ & $\begin{array}{l}\text { Analysed sexes separately } \\
\text { or tested interaction }\end{array}$ \\
\hline \multicolumn{8}{|l|}{ Wistar rats } \\
\hline \multirow{3}{*}{$\begin{array}{l}\text { Bellinger } \\
2005[21]\end{array}$} & \multirow[t]{3}{*}{5} & \multirow{3}{*}{$\begin{array}{l}\text { PR } \\
\text { (9\% vs } 18 \%)\end{array}$} & GD 0-7 & Hepatic & Behavioural & Body weight & \multirow[t]{3}{*}{ Interaction } \\
\hline & & & GD 8-14 & None & Behavioural & None & \\
\hline & & & GD 15-22 & Hepatic & Behavioural & Body weight & \\
\hline \multirow[t]{4}{*}{$\begin{array}{l}\text { Bellinger } \\
2006[22]\end{array}$} & \multirow[t]{4}{*}{$8-11$} & \multirow[t]{4}{*}{$\begin{array}{l}\text { PR } \\
\text { ( } 9 \% \text { vs } 18 \%)\end{array}$} & GD 0-birth & $\begin{array}{l}\text { Body weight; } \\
\text { fat }\end{array}$ & $\begin{array}{l}\text { Fat; } \\
\text { behavioural }\end{array}$ & None & \multirow[t]{4}{*}{ Interaction } \\
\hline & & & GD 0-7 & $\begin{array}{l}\text { Body weight; } \\
\text { fat; behavioural }\end{array}$ & $\begin{array}{l}\text { Body weight; } \\
\text { fat }\end{array}$ & None & \\
\hline & & & GD 8-14 & $\begin{array}{l}\text { Body weight; } \\
\text { behavioural }\end{array}$ & None & None & \\
\hline & & & GD 15-22 & $\begin{array}{l}\text { Body weight; } \\
\text { fat }\end{array}$ & $\begin{array}{l}\text { Fat; } \\
\text { behavioural }\end{array}$ & None & \\
\hline \multirow[t]{4}{*}{$\begin{array}{l}\text { Chamson-Reig } \\
2006 \text { [23] }\end{array}$} & \multirow[t]{4}{*}{$3-4$} & \multirow[t]{4}{*}{$\begin{array}{l}\text { PR } \\
\text { (8\% vs } 20 \%)\end{array}$} & $\begin{array}{l}\text { GD 0- } \\
\text { weaning }\end{array}$ & None & None & Pancreatic & \multirow[t]{4}{*}{ Interaction } \\
\hline & & & GD 0-14 & None & Pancreatic & Pancreatic & \\
\hline & & & GD 8-14 & None & Pancreatic & Pancreatic & \\
\hline & & & GD 15-22 & Pancreatic & Pancreatic & Pancreatic & \\
\hline \multirow{4}{*}{$\begin{array}{l}\text { Mallinson } \\
2007 \text { [33] }\end{array}$} & \multirow{4}{*}{$\begin{array}{l}11- \\
13\end{array}$} & \multirow{4}{*}{$\begin{array}{l}\text { PR } \\
\text { (9\% vs } 18 \%)\end{array}$} & GD 0-birth & Muscular & None & None & \multirow[t]{4}{*}{ Interaction } \\
\hline & & & GD 0-7 & Muscular & None & Muscular & \\
\hline & & & GD 8-14 & None & Muscular & Muscular & \\
\hline & & & GD 15-22 & None & None & Muscular & \\
\hline \multicolumn{8}{|c|}{ Sprague-Dawley rats } \\
\hline \multirow[t]{3}{*}{$\begin{array}{l}\text { Woods } \\
2004[54]\end{array}$} & \multirow[t]{3}{*}{$6-9$} & \multirow[t]{3}{*}{$\begin{array}{l}\text { PR } \\
\text { (5\% vs 19\%) }\end{array}$} & GD 1-birth & $\begin{array}{l}\text { Body weight; } \\
\text { renal }\end{array}$ & None & $\begin{array}{l}\text { Body weight; cardiovascular; } \\
\text { renal }\end{array}$ & \multirow[t]{3}{*}{$\begin{array}{l}\text { Sexes separately and } \\
\text { interaction }\end{array}$} \\
\hline & & & GD 1-11 & None & None & None & \\
\hline & & & GD 11-birth & $\begin{array}{l}\text { Body weight; } \\
\text { renal }\end{array}$ & None & Cardiovascular & \\
\hline
\end{tabular}

${ }^{\mathrm{a}}$ Sample size is provided as the number of dams per group (? = not stated)

$0.8 \times 0.8=0.64$, while the probability of being significant in neither sex is $0.2 \times 0.2=0.04$, and the probability of being significant in one sex but not the other is 0.32 . Therefore, even though the effect is similar in both sexes, there is a substantial probability that it will be reported as "sex-specific" if the sexes are analysed separately. As a result, many reports of sex-specific effects may in fact be false positives. Conversely, testing the sexes separately will miss some "sex-dependent" effects, i.e. those that are present in both sexes, but differ in magnitude. For example, our meta-analysis found that food restriction in the second half of gestation significantly increased adult blood pressure in both males and females, but that this effect was significantly greater in males. Tests of statistical interactions (e.g. between sex and early-life environment) have lower power than tests of main effects (e.g. effect of sex or effect of early-life environment). However, the solution to this issue is not to accept inadequate statistical approaches, but rather to increase sample sizes to provide appropriate power for robust testing.

Protein and food restriction in rodents is widely used to model prenatal malnutrition in pregnancy, which has clear effects on adult health in humans [13]. Contrary to the hypothesis that males are more sensitive to food shortage, women but not men exposed to famine in early gestation had higher adult mortality risk [87] and higher adult BMI [88]. In a separate cohort, famine exposure elevated adult blood pressure and increased the risk of hypertension in women only [89]. However, exposure to famine early in gestation affected brain size in males but not females [90], and exposure in the second trimester increased the risk of affective disorders in males only [91].

\section{Perspectives and significance}

A number of studies have suggested that males have greater susceptibility to early-life adversity, with some 
hypothesizing that reduced investment in placental growth makes males particularly vulnerable to poor nutrition. This hypothesis makes clear predictions that (1) males will be more affected by food and protein restriction, and (2) effects will be particularly severe if nutrition is reduced part-way through gestation. We reviewed rat and mouse studies of food and protein restriction to test these predictions and found little support for either. Future work should examine potential sex-dependent effects with robust statistical approaches (e.g. interaction terms) to avoid both false positives (i.e. effects that are erroneously reported as sex-specific) and false negatives (i.e. effects that are not recognized as sex-dependent because they are significant in both sexes, even though they differ in magnitude).

\section{Supplementary Information}

The online version contains supplementary material available at https://doi. org/10.1186/s13293-021-00365-4

Additional file 1: Data extracted from 65 studies meeting eligibility

criteria, including more detailed data extracted for meta-analyses.

\section{Abbreviations}

BMI: Body mass index; FR: Food restriction; GD: Gestational day; PR: Protein restriction

\section{Acknowledgements}

We thank two anonymous reviewers for constructive comments, including the suggestion to perform meta-analyses.

\section{Authors' contributions}

JKC and HKS performed the literature searches and screens of titles and abstracts and extracted data from studies matching search criteria. JKC conceived the study and wrote the manuscript. AYKA performed the metaanalyses. The authors read and approved the final manuscript.

\section{Funding}

This study was funded by a Natural Sciences and Engineering Research Council of Canada Discovery Grant (JKC; grant number RGPIN-2016-04047). The funding bodies had no role in study design, collection and interpretation of data, or manuscript preparation.

\section{Availability of data and materials}

This review was based on published data.

\section{Ethics approval and consent to participate}

This study was based on published work and therefore did not require approval by an institutional committee.

\section{Consent for publication}

Not applicable.

\section{Competing interests}

The authors declare that they have no competing interests.

\section{Author details}

${ }^{1}$ Department of Biological Sciences, Simon Fraser University, 8888 University Drive, Burnaby, British Columbia V5A 156, Canada. ${ }^{2}$ Centre for Cell Biology, Development and Disease, Simon Fraser University, Burnaby, Canada. ${ }^{3}$ British Columbia Children's Hospital Research Institute, Vancouver, BC, Canada. ${ }^{4}$ Women's Health Research Institute, BC Women's Hospital and Health Centre, Vancouver, British Columbia, Canada.
Received: 10 September 2020 Accepted: 31 January 2021

Published online: 09 February 2021

\section{References}

1. Sutherland S, Brunwasser SM. Sex differences in vulnerability to prenatal stress: a review of the recent literature. Curr Psychiatry Rep. 2018;20:102 United States.

2. Sandman CA, Glynn LM, Davis EP. Is there a viability-vulnerability tradeoff? Sex differences in fetal programming. J Psychosom Res. 2013;75:327-35 England.

3. Carpenter T, Grecian SM, Reynolds RM. Sex differences in early-life programming of the hypothalamic-pituitary-adrenal axis in humans suggest increased vulnerability in females: a systematic review. J Dev Orig Health Dis. 2017:8:244-55 England.

4. DiPietro JA, Voegtline KM. The gestational foundation of sex differences in development and vulnerability. Neuroscience. 2017;342:4-20 United States.

5. Glover $\mathrm{V}$, Hill J. Sex differences in the programming effects of prenatal stress on psychopathology and stress responses: an evolutionary perspective. Physiol Behav. 2012;106:736-40 United States.

6. Dearden L, Bouret SG, Ozanne SE. Sex and gender differences in developmental programming of metabolism. Mol Metab. 2018;15:8-19 Germany.

7. Moritz KM, Cuffe JSM, Wilson LB, Dickinson H, Wlodek ME, Simmons DG, et al. Review: Sex specific programming: A critical role for the renal reninangiotensin system. Placenta. 2010;24:S40-6.

8. Morton JS, Cooke C-L, Davidge ST. In utero origins of hypertension: mechanisms and targets for therapy. Physiol Rev. 2016;96:549-603.

9. Eriksson JG, Kajantie E, Osmond C, Thornburg K, Barker DJP. Boys live dangerously in the womb. Am J Hum Biol. 2010;22:330-5 United States.

10. Isaac JL. Potential causes and life-history consequences of sexual size dimorphism in mammals. Mammal Rev. 2005:35:101-15.

11. Cassini MH. Sexual size dimorphism and sexual selection in primates. Mammal Rev. 2020;50:231-9.

12. Kuzawa CW, McDade TW, Adair LS, Lee N. Rapid weight gain after birth predicts life history and reproductive strategy in Filipino males. Proc Natl Acad Sci U S A. 2010;107:16800-5.

13. Roseboom T, de Rooij S, Painter R. The Dutch famine and its long-term consequences for adult health. Early Hum Dev. 2006;82:485-91.

14. Li M, Sloboda DM, Vickers MH. Maternal obesity and developmental programming of metabolic disorders in offspring: evidence from animal models. Exp Diabetes Res. 2011;2011:592408.

15. Christians JK, Lennie Kl, Wild LK, Garcha R. Effects of high-fat diets on fetal growth in rodents: a systematic review. Reprod Biol Endocrinol. 2019;17:39 England.

16. Ainge $H$, Thompson C, Ozanne SE, Rooney KB. A systematic review on animal models of maternal high fat feeding and offspring glycaemic control. Int J Obes. 2011;35:325-35.

17. Moher D, Liberati A, Tetzlaff J, Altman DG, The PRISMA Group. Preferred reporting items for systematic reviews and meta-analyses: The PRISMA statement. PLoS Med. 2009;6:e1000097.

18. Rohatgi A. Webplotdigitizer: Version 4.4. 2020. Available from: https://a utomeris.io/WebPlotDigitizer

19. Viechtbauer W. Conducting meta-analyses in $\mathrm{R}$ with the metafor package. J Stat Softw. 2010:36:1-48.

20. Alwasel SH, Ashton N. Prenatal programming of renal sodium handling in the rat. Clin Sci (Lond). 2009;117:75-84.

21. Bellinger $L$, Langley-Evans SC. Fetal programming of appetite by exposure to a maternal low-protein diet in the rat. Clin Sci (Lond). 2005:109:413-20.

22. Bellinger L, Sculley DV, Langley-Evans SC. Exposure to undernutrition in fetal life determines fat distribution, locomotor activity and food intake in ageing rats. Int J Obes. 2006:30:729-38.

23. Chamson-Reig A, Thyssen SM, Arany E, Hill DJ. Altered pancreatic morphology in the offspring of pregnant rats given reduced dietary protein is time and gender specific. J Endocrinol. 2006;191:83-92.

24. Cooke $\mathrm{CL}$, Zhao L, Gysler S, Arany E, Regnault TRH. Sex-specific effects of low protein diet on in utero programming of renal G-protein coupled receptors. J Dev Orig Health Dis. 2014;5:36-44.

25. Desai M, Byrne CD, Meeran K, Martenz ND, Bloom SR, Hales CN. Regulation of hepatic enzymes and insulin levels in offspring of rat dams fed a reduced-protein diet. Am J Phys. 1997;273:G899-904. 
26. Elmes MJ, Gardner DS, Langley-Evans SC. Fetal exposure to a maternal lowprotein diet is associated with altered left ventricular pressure response to ischaemia-reperfusion injury. Br J Nutr. 2007;98:93-100.

27. Elmes MJ, Haase A, Gardner DS, Langley-Evans SC. Sex differences in sensitivity to beta-adrenergic agonist isoproterenol in the isolated adult rat heart following prenatal protein restriction. Br J Nutr. 2009;101:725-34.

28. Kwong WY, Miller DJ, Ursell E, Wild AE, Wilkins AP, Osmond C, et al. Imprinted gene expression in the rat embryo-fetal axis is altered in response to periconceptional maternal low protein diet. Reproduction. 2006;132:265-77.

29. Kwong WY, Miller DJ, Wilkins AP, Dear MS, Wright JN, Osmond C, et al. Maternal low protein diet restricted to the preimplantation period induces a gender-specific change on hepatic gene expression in rat fetuses. Mol Reprod Dev. 2007;74:48-56.

30. Langley-Evans SC. Hypertension induced by foetal exposure to a maternal low-protein diet, in the rat, is prevented by pharmacological blockade of maternal glucocorticoid synthesis. J Hypertens. 1997;15:537-44.

31. Langley-Evans SC, Sculley DV. Programming of hepatic antioxidant capacity and oxidative injury in the ageing rat. Mech Ageing Dev. 2005;126:804-12.

32. Langley-Evans SC, Lilley C, McMullen S. Maternal protein restriction and fetal growth: lack of evidence of a role for homocysteine in fetal programming. Br J Nutr. 2006;96:578-86

33. Mallinson JE, Sculley DV, Craigon J, Plant R, Langley-Evans SC, Brameld JM. Fetal exposure to a maternal low-protein diet during mid-gestation results in muscle-specific effects on fibre type composition in young rats. $\mathrm{Br} J$ Nutr. 2007;98:292-9

34. McMullen S, Langley-Evans SC. Maternal low-protein diet in rat pregnancy programs blood pressure through sex-specific mechanisms. Am J Phys Regul Integr Comp Phys. 2005;288:R85-90.

35. McMullen S, Langley-Evans SC. Sex-specific effects of prenatal low-protein and carbenoxolone exposure on renal angiotensin receptor expression in rats. Hypertension. 2005;46:1374-80.

36. Pires KMP, Aguila MB, Mandarim-de-Lacerda CA. Early renal structure alteration in rat offspring from dams fed low protein diet. Life Sci. 2006;79: 2128-34.

37. Tang C, Marchand K, Lam L, Lux-Lantos V, Thyssen SM, Guo J, et al. Maternal taurine supplementation in rats partially prevents the adverse effects of early-life protein deprivation on beta-cell function and insulin sensitivity. Reproduction. 2013;145:609-20.

38. Theys N, Bouckenooghe T, Ahn M-T, Remacle C, Reusens B. Maternal lowprotein diet alters pancreatic islet mitochondrial function in a sex-specific manner in the adult rat. Am J Phys Regul Integr Comp Phys. 2009;297: R1516-25.

39. Torrens C, Kelsall CJ, Hopkins LA, Anthony FW, Curzen NP, Hanson MA Atorvastatin restores endothelial function in offspring of protein-restricted rats in a cholesterol-independent manner. Hypertension. 2009;53:661-U125.

40. Vega CC, Reyes-Castro LA, Rodriguez-Gonzalez GL, Bautista CJ, VazquezMartinez M, Larrea F, et al. Resveratrol partially prevents oxidative stress and metabolic dysfunction in pregnant rats fed a low protein diet and their offspring. J Physiol. 2016;594:1483-99.

41. Ye W, Pitlock MD, Javors MA, Thompson BJ, Lechleiter JD, Hensler JG. The long-term effect of maternal dietary protein restriction on 5-HT1A receptor function and behavioral responses to stress in adulthood. Behav Brain Res. 2018;349:116-24

42. Zambrano E, Bautista CJ, Deas M, Martinez-Samayoa PM, GonzalezZamorano $\mathrm{M}$, Ledesma $\mathrm{H}$, et al. A low maternal protein diet during pregnancy and lactation has sex- and window of exposure-specific effects on offspring growth and food intake, glucose metabolism and serum leptin in the rat. J Physiol. 2006;571:221-30.

43. Howie GJ, Sloboda DM, Vickers MH. Maternal undernutrition during critical windows of development results in differential and sex-specific effects on postnatal adiposity and related metabolic profiles in adult rat offspring. $\mathrm{Br} J$ Nutr. 2012;108:298-307.

44. Ozaki T, Nishina H, Hanson MA, Poston L. Dietary restriction in pregnant rats causes gender-related hypertension and vascular dysfunction in offspring. J Physiol. 2001;530:141-52

45. Peiris HN, Ponnampalam AP, Mitchell MD, Green MP. Brief Communication: Sexual dimorphic expression of myostatin and follistatin like-3 in a rat transgenerational under-nutrition model. Nutr Metab (Lond). 2010;7:44.

46. Sanchez-Garrido MA, Castellano JM, Ruiz-Pino F, Garcia-Galiano D, ManfrediLozano M, Leon S, et al. Metabolic programming of puberty: sexually dimorphic responses to early nutritional challenges. Endocrinology. 2013; 154:3387-400.

47. Sardinha FLC, Telles MM, Albuquerque KT, Oyama LM, Guimaraes PAMP, Santos OFP, et al. Gender difference in the effect of intrauterine malnutrition on the central anorexigenic action of insulin in adult rats. Nutrition. 2006;22:1152-61

48. Zhang L, Xu D, Zhang B, Liu Y, Chu F, Guo Y, et al. Prenatal food restriction induces a hypothalamic-pituitary-adrenocortical axis-associated neuroendocrine metabolic programmed alteration in adult offspring rats. Arch Med Res. 2013;44:335-45.

49. Claycombe KJ, Vomhof-DeKrey EE, Roemmich JN, Rhen T, Ghribi O. Maternal low-protein diet causes body weight loss in male, neonate Sprague-Dawley rats involving UCP-1-mediated thermogenesis. J Nutr Biochem. 2015;26:72935.

50. DuBois B, Pearson J, Hastings B, Mahmood T, Chan T, Alnakhli A, et al. Maternal low-protein diet alters the expression of real-time quantitative polymerase chain reaction reference genes in an age-, sex-, and organdependent manner in rat offspring. Nutr Res. 2013;33:235-41.

51. Gao H, Sathishkumar KR, Yallampalli U, Balakrishnan M, Li X, Wu G, et al. Maternal protein restriction regulates IGF2 system in placental labyrinth. Front Biosci (Elite Ed). 2012;4:1434-50.

52. Gao H, Yallampalli U, Yallampalli C. Maternal protein restriction reduces expression of angiotensin I-converting enzyme 2 in rat placental labyrinth zone in late pregnancy. Biol Reprod. 2012;86.

53. Sathishkumar K, Balakrishnan M, Chinnathambi V, Gao H, Yallampalli C. Temporal alterations in vascular angiotensin receptors and vasomotor responses in offspring of protein-restricted rat dams. Am J Obstet Gynecol. 2012;206(6):507.e1-10.

54. Woods LL, Weeks DA, Rasch R. Programming of adult blood pressure by maternal protein restriction: role of nephrogenesis. Kidney Int. 2004;65: 1339-48.

55. Woods $L L$, Ingelfinger JR, Rasch R. Modest maternal protein restriction fails to program adult hypertension in female rats. Am J Physiol Integr Comp Physiol. 2005;289:R1131-6.

56. Choi GY, Tosh DN, Garg A, Mansano R, Ross MG, Desai M. Gender-specific programmed hepatic lipid dysregulation in intrauterine growth-restricted offspring. Am J Obstet Gynecol. 2007;196:477.e1-7.

57. Desai M, Gayle D, Babu J, Ross MG. Permanent reduction in heart and kidney organ growth in offspring of undernourished rat dams. Am J Obstet Gynecol. 2005;193:1224-32

58. Desai M, Babu J, Ross MG. Programmed metabolic syndrome: prenatal undernutrition and postweaning overnutrition. Am J Phys Regul Integr Comp Phys. 2007;293:R2306-14.

59. Gutierrez-Arzapalo PY, Rodriguez-Rodriguez P, Ramiro-Cortijo D, de Pablo AL, Rosario Lopez-Gimenez M, Condezo-Hoyos L, et al. Role of fetal nutrient restriction and postnatal catch-up growth on structural and mechanical alterations of rat aorta. J Physiol. 2018;596:5791-806.

60. Hemmings DG, Williams SJ, Davidge ST. Increased myogenic tone in 7month-old adult male but not female offspring from rat dams exposed to hypoxia during pregnancy. Am J Physiol Heart Circ Physiol. 2005;289:H67482.

61. Khorram NM, Magee TR, Wang C, Desai M, Ross M, Khorram O. Maternal undernutrition programs offspring adrenal expression of steroidogenic enzymes. Reprod Sci. 2011;18:931-40.

62. Lee $\mathrm{S}$, Lee KA, Choi GY, Desai M, Lee SH, Pang M-G, et al. Feed restriction during pregnancy/lactation induces programmed changes in lipid, adiponectin and leptin levels with gender differences in rat offspring. J Matern Fetal Neonatal Med. 2013;26:908-14.

63. Matveyenko AV, Singh I, Shin B-C, Georgia S, Devaskar SU. Differential effects of prenatal and postnatal nutritional environment on ss-cell mass development and turnover in male and female rats. Endocrinology. 2010; 151:5647-56.

64. Dalle Molle R, Laureano DP, Alves MB, Reis TM, Desai M, Ross MG, et al. Intrauterine growth restriction increases the preference for palatable foods and affects sensitivity to food rewards in male and female adult rats. Brain Res. 1618;2015:41-9.

65. Munoz-Valverde D, Rodríguez-Rodríguez P, Gutierrez-Arzapalo PY, de Pablo AL, Carmen González M, López-Giménez R, et al. Effect of fetal undernutrition and postnatal overfeeding on rat adipose tissue and organ growth at early stages of postnatal development. Physiol Res. 2015;64:54759. 
66. Paek DS, Sakurai R, Saraswat A, Li Y, Khorram O, Torday JS, et al. Metyrapone alleviates deleterious effects of maternal food restriction on lung development and growth of rat offspring. Reprod Sci. 2015;22:207-22.

67. Rodríguez-Rodríguez P, de Pablo ALLL, Condezo-Hoyos L, Martín-Cabrejas MA, Aguilera Y, Ruiz-Hurtado G, et al. Fetal undernutrition is associated with perinatal sex-dependent alterations in oxidative status. J Nutr Biochem. 2015;26:1650-9

68. Rodriguez-Rodriguez P, Lopez de Pablo AL, Garcia-Prieto CF, Somoza B, Quintana-Villamandos BB, Gomez de Diego JJ, et al. Long term effects of fetal undernutrition on rat heart. Role of hypertension and oxidative stress. PLoS One. 2017;12:e0171544.

69. You Y-A, Lee JH, Kwon EJ, Yoo JY, Kwon W-S, Pang M-G, et al. Proteomic analysis of one-carbon metabolism-related marker in liver of rat offspring. Mol Cell Proteomics. 2015;14:2901-9.

70. Black MJ, Lim K, Zimanyi MA, Sampson AK, Bubb KJ, Flower RL, et al. Accelerated age-related decline in renal and vascular function in female rats following early-life growth restriction. Am J Phys Regul Integr Comp Phys. 2015;309:R1153-61.

71. Palmer AA, Printz DJ, Butler PD, Dulawa SC, Printz MP. Prenatal protein deprivation in rats induces changes in prepulse inhibition and NMDA receptor binding. Brain Res. 2004;996:193-201.

72. Harvey TJ, Murphy RM, Morrison JL, Posterino GS. Maternal nutrient restriction alters $\mathrm{Ca} 2+$ handling properties and contractile function of isolated left ventricle bundles in male but not female juvenile rats. PLoS One. 2015;10(9):e0138388.

73. Roghair RD, Segar JL, Volk KA, Chapleau MW, Dallas LM, Sorenson AR, et al Vascular nitric oxide and superoxide anion contribute to sex-specific programmed cardiovascular physiology in mice. Am J Phys Regul Integr Comp Phys. 2009;296:R651-62.

74. van Straten EME, Bloks VW, van Dijk TH, Baller JFW, Huijkman NCA, Kuipers I, et al. Sex-dependent programming of glucose and fatty acid metabolism in mouse offspring by maternal protein restriction. Gend Med. 2012;9:166-79.

75. Whitaker KW, Totoki K, Reyes TM. Metabolic adaptations to early life protein restriction differ by offspring sex and post-weaning diet in the mouse. Nutr Metab Cardiovasc Dis. 2012;22:1067-74.

76. Ito T, Tanabe K, Nakamura A, Funamoto K, Aoyagi A, Sato K, et al. Aberrant expression of hypoxia-inducible factor $1 a$ in the fetal heart is associated with maternal undernutrition. Tohoku J Exp Med. 2011;224:163-71.

77. Belluscio LM, Berardino BG, Ferroni NM, Ceruti JM, Canepa ET. Early protein malnutrition negatively impacts physical growth and neurological reflexes and evokes anxiety and depressive-like behaviors. Physiol Behav. 2014;129: 237-54.

78. Goyal R, Longo LD. Maternal protein deprivation: sexually dimorphic programming of hypertension in the mouse. Hypertens Res. 2013;36: 29-35.

79. Goyal R, Wong C, Van Wickle J, Longo LD. Antenatal maternal protein deprivation: sexually dimorphic programming of the pancreatic reninangiotensin system. J Renin-Angiotensin-Aldosterone Syst. 2013;14: $137-45$

80. Baldauf C, Sondhi M, Shin B-C, Ko YE, Ye X, Lee K-W, et al. Murine maternal dietary restriction affects neural Humanin expression and cellular profile. J Neurosci Res. 2020:98:902-20.

81. Chen P-Y, Ganguly A, Rubbi L, Orozco LD, Morselli M, Ashraf D, et al. Intrauterine calorie restriction affects placental DNA methylation and gene expression. Physiol Genomics. 2013;45:565-76.

82. Srugo SA, Bloise E, Nguyen TT-TN, Connor KL. Impact of maternal malnutrition on gut barrier defense: implications for pregnancy health and fetal development. Nutrients. 2019;11.

83. Akitake $Y$, Katsuragi S, Hosokawa M, Mishima K, Ikeda T, Miyazato M, et al. Moderate maternal food restriction in mice impairs physical growth, behavior, and neurodevelopment of offspring. Nutr Res. 2015; 35:76-87.

84. Harper JL, Caesar GA, Pennington KA, Davis JW, Schulz LC. Placental changes caused by food restriction during early pregnancy in mice are reversible. Reproduction. 2015;150:165-72.

85. Chin EH, Christians JK. When are sex-specific effects really sex-specific? J Dev Orig Health Dis. 2015;6:438-42.

86. Dumas-Mallet E, Button KS, Boraud T, Gonon F, Munafò MR. Low statistical power in biomedical science: A review of three human research domains. $R$ Soc Open Sci. 2017;4:160254.
87. Van Abeelen AFM, Veenendaal MVE, Painter RC, De Rooij SR, Dijkgraaf MGW, Bossuyt PMM, et al. Survival effects of prenatal famine exposure. Am J Clin Nutr. 2012;95:179-83.

88. Ravelli ACJ, Van Der Meulen JHP, Osmond C, Barker DJP, Bleker OP. Obesity at the age of $50 \mathrm{y}$ in men and women exposed to famine prenatally. Am J Clin Nutr. 1999;70:811-6.

89. Chen H, Nembhard WN, Stockwell HG. Sex-specific effects of fetal exposure to the 1959-1961 Chinese famine on risk of adult hypertension. Matern Child Health J. 2014;18:527-33.

90. De Rooij SR, Caan MWA, Swaab DF, Nederveen AJ, Majoie CB, Schwab M, et al. Prenatal famine exposure has sex-specific effects on brain size. Brain 2016;139:2136-42.

91. Brown AS, Susser ES, Lin SP, Neugebauer R, Gorman JM. Increased risk of affective disorders in males after second trimester prenatal exposure to the Dutch hunger winter of 1944-45. Br J Psychiatry. 1995;166:601-6.

\section{Publisher's Note}

Springer Nature remains neutral with regard to jurisdictional claims in published maps and institutional affiliations.

Ready to submit your research? Choose BMC and benefit from:

- fast, convenient online submission

- thorough peer review by experienced researchers in your field

- rapid publication on acceptance

- support for research data, including large and complex data types

- gold Open Access which fosters wider collaboration and increased citations

- maximum visibility for your research: over $100 \mathrm{M}$ website views per year

At $\mathrm{BMC}$, research is always in progress.

Learn more biomedcentral.com/submissions 